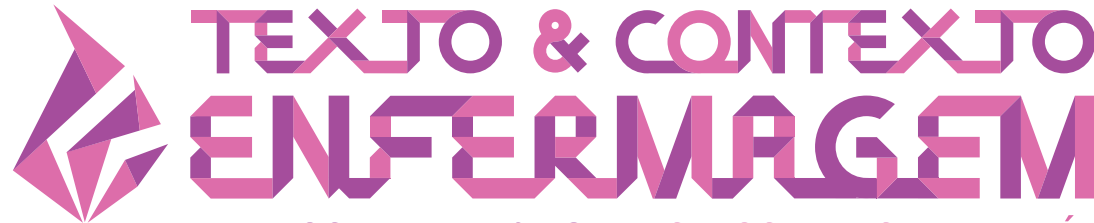

TEXT \& CONTEXT NURSING TEXTO \& CONTEXTO ENFERMERÍA

\section{FACTORS ASSOCIATED TO ALCOHOL USE BY ADOLESCENTS}

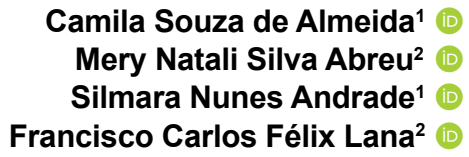

${ }^{1}$ Universidade do Estado de Minas Gerais. Divinópolis, Minas Gerais, Brasil. ¿Universidade Federal de Minas Gerais. Belo Horizonte, Minas Gerais, Brasil.

\begin{abstract}
Objective: to analyze the association between alcohol use by adolescents and environmental, family and social relations factors.

Method: and epidemiological study, of the cross-sectional cohort type, with a sample consisting of 303 students from the Brazilian $9^{\text {th }}$ grade of elementary level of public and private schools in Divinópolis, Minas Gerais, Brazil. Data was collected through the replication of the "General Information" and "Use of Alcohol" modules from the National Survey of School Health - 2015. The answer variable was alcohol consumption in life, associating it with explanatory variables related to: living with parents, maternal schooling, administrative dependency of the school, alcohol use by friends, and future perspectives. Univariate and multivariate analyses were used using Pearson's chi-square tests and Poisson's model for robust variances.

Results: an association was found in the multivariate analysis between consumption of beverages and intending to study only until high school or technical school $(p=0.007)$, continuing to study and work $(p=0.003)$, not living with parents $(p=0.010)$, and having friends who make use alcohol $(p=0.009)$.

Conclusion: social relationships were the most relevant factor for alcohol consumption by adolescents, mainly influenced by friends who use it and by the interpersonal relationships established by them.
\end{abstract}

DESCRIPTORS: Adolescents. Cross-sectional studies. School health services. Adolescent behavior. Disorders related to substance use. Alcoholism. 


\section{FATORES ASSOCIADOS AO USO DE ÁLCOOL POR ADOLESCENTES}

\section{RESUMO}

Objetivo: analisar a associação entre uso de álcool por adolescentes e os fatores ambientais, familiares e de relações sociais.

Método: estudo epidemiológico, de coorte transversal, com amostra constituída por 303 estudantes do $9^{\circ}$ ano do ensino fundamental de escolas públicas e particulares de Divinópolis, Minas Gerais, Brasil. Os dados foram coletados por meio da replicação dos módulos "Informações Gerais" e "Uso de Álcool" da Pesquisa Nacional de Saúde do Escolar - 2015. A variável resposta foi consumo de álcool na vida, associando-a a variáveis explicativas relacionadas com: morar com os pais, escolaridade materna, dependência administrativa da escola, uso de álcool por amigos e perspectivas futuras. Utilizou-se de análise univariada e multivariada por meio dos testes de qui-quadrado de Pearson e modelo de Poisson para as variâncias robustas.

Resultados: obteve-se associação na análise multivariada entre fazer uso de bebidas e pretender estudar apenas até o ensino médio ou técnico $(p=0,007)$, continuar a estudar e trabalhar $(p=0,003)$, não morar com os pais $(p=0,010)$ e ter amigos que fazem uso de álcool $(p=0,009)$.

Conclusão: as relações sociais foram o fator mais relevante para o uso de álcool por adolescentes, influenciado principalmente pelos amigos que fazem o uso e as relações interpessoais estabelecidas por eles.

DESCRITORES: Adolescentes. Estudos transversais. Serviços de saúde escolar. Comportamento do adolescente. Transtornos relacionados ao uso de substância. Alcoolismo.

\section{FACTORES ASOCIADOS AL CONSUMO DE ALCOHOL POR PARTE DE ADOLESCENTES}

\section{RESUMEN}

Objetivo: analizar la asociación entre el consumo de alcohol por parte de adolescentes y los factores ambientales, familiares y de relaciones sociales.

Método: estudio epidemiológico de coorte transversal, con una muestra constituida por 303 estudiantes del $9^{\circ}$ año do enseñanza fundamental de escuelas públicas y privadas de Divinópolis, Minas Gerais, Brasil. Los datos se recolectaron por medio de la replicación de los módulos de "Información general" y "Consumo de Alcohol" de la Investigación Nacional de Salud Escolar - 2015. La variable de respuesta fue el consumo de alcohol en la vida, asociándola a las variables explicativas relacionadas con lo siguiente: vivir con los padres, escolaridad materna, dependencia administrativa de la escuela, consumo de alcohol en amigos y perspectivas a futuro. Se empleó análisis univariado y multivariado por medio de las pruebas de chi-cuadrado de Pearson y el modelo de Poisson para las varianzas robustas.

Resultados: se obtuvo una asociación en el análisis multivariado entre consumir bebidas alcohólicas y tener pensado estudiar solamente hasta el nivel medio o técnico $(p=0,007)$, seguir estudiando y trabajar $(p=0,003)$, no vivir con los padres $(p=0,010)$ y tener amigos que consumen alcohol $(p=0,009)$.

Conclusión: las relaciones sociales fueron el factor más relevante para el consumo de alcohol por parte de los adolescentes, influenciado principalmente por los amigos que lo consumen y por las relaciones interpersonales por ellos establecidas.

DESCRIPTORES: Adolescentes. Estudios transversales. Servicios de salud escolar. Comportamiento del adolescente. Trastornos relacionados con el uso de substancias. Alcoholismo. 


\section{INTRODUCTION}

The use of alcohol is found in practically all cultures, including the Brazilian one. ${ }^{1}$ There is a perception that "everyone drinks" and that leisure is related to this act. Few events in the country occur without the sale of beverages, as well as their linkage in advertisements and even sponsorship of sporting events. ${ }^{2}$ The overexposure to alcohol also occurs in the social networks where adolescents post photos with drinks and in places where it is sold, making consumption desirable and a source of social inclusion. ${ }^{3}$

A national study carried out in 2012 showed that $50 \%$ of the population used alcohol, of which $6.8 \%$ were dependent and $16 \%$ drank in excess; in addition, $7.1 \%$ of the women and $27.3 \%$ of the men drank and drove,${ }^{4}$ which can lead to automobile accidents, as pointed out in the 2013 National Health Survey, in which it was verified that, in the 12 months preceding the survey, $3.1 \%$ of the general population had been involved in a traffic accident with bodily injuries, with this number practically doubling among individuals who reported alcohol use, with a prevalence of $6.1 \%{ }^{5}$

Regarding adolescents, the 2015 National School Health Survey (Pesquisa Nacional de Saúde do Escolar, PeNSE 2015) ${ }^{6}$ showed that, in the last month, $23.8 \%$ used alcoholic beverages, with the prevalence in boys being $22.5 \%$ and in girls, $25.1 \%$. The prevalence of lifetime use was $55.5 \%$ in an adolescent from the $9^{\text {th }}$ grade of elementary school. ${ }^{6}$

Adolescents have started drinking at an early age, with a mean age of 13 years old or younger. ${ }^{7-8}$ The earlier the beginning of use, the greater the chances of abuse in adulthood, especially if this use is in the binge drinking pattern. ${ }^{9}$ A study carried out in Australia reports that the use of alcohol in adolescence predisposes to worse levels of health in adulthood. ${ }^{10}$ As brain development can be altered, influences can occur on behavioral, emotional and social development, ${ }^{11}$ in addition to increasing dopamine levels, mainly in the prefrontal cortex, playing an important role in the system of reward. ${ }^{7}$

Early use is also related to school failure, with school dropping out and repeating, increased violent and risky behaviors, such as early sexual initiation, unprotected sex, and may be a trigger for the use of other drugs, ${ }^{2,4}$ but both international and national surveys are inconclusive and contradictory in several factors related to the use of alcohol by adolescents, as in the case of the school administrative dependency. The 2015 National School Health Survey reports greater use among adolescents in private schools and among those who miss classes and suffer bullying, while other studies show greater use among students from private schools. The fact would be due to the greater purchasing power and to the use in the binge drinking pattern. ${ }^{12-13}$

The same occurs when analyzing family income and the consumption of beverages by adolescents; a study carried out in Uberlândia, Minas Gerais, reports greater use in families with an income above three minimum wages; however, in a research study conducted in Diamantina, Minas Gerais, low income was associated with alcohol use by adolescents. ${ }^{14}$

The use of alcohol by adolescents is thematic-complex and more research studies with different samples and scenarios are extremely important to understand the characteristics of use, with the aim of improving the Public Policies and interventions for this population.

Bearing in mind the importance of this situation, the school is a favorable environment for knowledge of the reality of alcohol use, as well as a privileged space for the implementation of Public Policies. Because of this, the monitoring of chronic noncommunicable diseases (CNCDs), such as the use of alcohol, has a privileged place in the school for research studies and interventions. ${ }^{15}$ 
Thus, research must be carried out to know the reality of the students. With this purpose in mind, the Brazilian Institute of Geography and Statistics (Instituto Brasileiro de Geografia e Estatística, IBGE) and the Ministry of Health (MoH) conceived in 2009 the National School Health Survey (PeNSE), whose objective is the monitoring of risk factors for the health of Brazilian adolescents, and two other editions have already been prepared, in 2012 and the last one in $2015 .^{6}$

Based on the relevance of the theme, the following question is asked: What are the environmental, social and family relation factors of these adolescents that are associated with the use of alcoholic beverages in a medium-sized municipality?

The present work reapplied the "general information" and "alcoholic beverages" modules of PeNSE(2015), ${ }^{6}$ in a city in the inland of Minas Gerais, in order to analyze whether the indexes and factors of alcohol use per adolescent in the inland of the country correspond to the rates presented in the National survey, in addition to analyzing the factors associated with the use by these young people. Aiming to: analyze the association between alcohol use by adolescents based on environmental, family and social relations factors.

\section{METHOD}

A cross-sectional and epidemiological study, carried out from May to July 2017 , with $9^{\text {th }}$ grade elementary school students from public and private schools in Divinópolis, Minas Gerais. The city is medium-sized, being a reference in the Midwest of Minas Gerais, with a population of over 200,000 inhabitants, and with an urban profile.

The sampling plan followed the standards used in the original PeNSE (2015) survey, ${ }^{6}$ with a sampling stratified by clusters in two stages. In the first stage, the schools in the sample were selected from a register of all schools in the city that had $9^{\text {th }}$ grade classes in 2017 . There were 53 schools listed, 10 private and 43 public, with approximately $1009^{\text {th }}$ grade classes and 3,000 students. Subsequently, two allocation strata were created represented by the administrative dependency (public or private) of the schools and the sample size was distributed proportionally to the size of these two strata, measured by the number of $9^{\text {th }}$ grade classes that each one presented in the register.

The sample size was calculated to provide estimates of the prevalence of alcohol consumption in the past 30 days by $9^{\text {th }}$ grade adolescents, estimated at around $23 \%$ for Minas Gerais and Brazil according to PeNSE (2015) data. Considering a population of 3,000 $9^{\text {th }}$ grade students, with a maximum sampling error of $5 \%$, in absolute values, $95 \%$ confidence level, and effect of the sampling plan (effect of cluster design) of 1.5 , a sample of approximately $3759^{\text {th }}$ grade students was estimated.

Given the mean number of approximately 30 students per class, according to registration, a sample of approximately 13 classes $(=375 / 30)$ was estimated, proportionally distributed among the allocation strata of public and private schools, therefore consisting of two classes of private schools and 11 public schools, with each class selected in each school drawn. In total, 303 questionnaires were applied in the 13 schools drawn. The schools were randomly selected, covering different locations in the city, increasing the diversity of the sample.

The following inclusion criteria were listed: being a $9^{\text {th }}$ grade elementary school student in the selected schools. All $9^{\text {th }}$ grade classes in the selected schools were visited prior to the beginning of data collection and received information and clarifications about the research. For those who agreed to participate, the Free and Informed Consent Form (FICF) was sent to their parents/guardians to consent to their participation. A monitor was asked to help the students who had some limitation to answer the questionnaire. 
The questionnaire applied corresponded to the general information and alcoholic beverages modules of PeNSE (2015), ${ }^{6}$ being administered in the classroom and completed by the students without the presence of teachers or school staff, so that the participants would not feel intimidated. Total anonymity was guaranteed to the interviewees. All the students who had the FICF signed by their parents/guardians and the Assent Form signed by them participated in the research.

For the study of the association between environmental, family and social relations factors, the answer variable used was alcohol consumption in life, obtained through the following question: "Have you ever had a drink of alcoholic beverages (one dose is equivalent to a can of beer or a glass of wine or a dose of sugarcane liquor or whiskey, etc.)? " categorized in yes or no. It was decided to use the question of alcohol use in life because it is more embracing and captures the experimentation of alcohol by adolescents at some point in their life, thus achieving a dialog with the other issues associated with the outcome. If use were limited to the last 30 days, the extent of the phenomenon would be lost, as the present work focuses on relating the factors that lead adolescents to alcohol use, at any time. In addition to the use of this variable in other studies on the subject being prevalent. ${ }^{7,11}$

The explanatory variables were grouped into four categories of covariates: the first encompassed the student's unique characteristics, with indicators as to gender (male/female); if the adolescent worked (yes/no); receiving some remuneration (yes/no); factors referring to plans for the future: expected schooling (graduate studies/undergraduate studies/until high school or technical school/does not know) and once the school cycle is finished, what do they intend to do (only continue studying/ only work/continue studying and working/follow another plan/does not know). The second category referred to the family context in which maternal schooling was analyzed (studied until elementary/high school or higher education) and who do they live with (father and mother/only mother/neither father nor mother); the category about the environment included school administrative dependency (public or private); and the fourth category, their social context, by means of the question about friends who drink (yes/no).

Data entry was performed concurrently with the collection period, and such information was stored and organized in an electronic spreadsheet, in the Excel for Windows program (Office 2013). After checking and correcting inconsistencies in the typing, the data were analyzed electronically with the aid of the STATA statistical program, version 12.0. A descriptive analysis of all the variables studied was performed and the prevalence of alcohol consumption in life was estimated with the respective $95 \%$ confidence interval $(95 \% \mathrm{Cl})$. To assess possible factors associated with alcohol consumption, in the univariate analysis, Pearson's chi-square test was used. For robust variances, the Poisson's model was used, both uni- and multi-variate. For the entry of variables in the multivariate analysis, a p-value below 0.20 was used as a reference in the univariate analysis. In the final model, only variables with a significance level of $5 \%$ or less remained. The Prevalence Ratio (PR) values were estimated, with a $95 \%$ confidence interval $(95 \% \mathrm{Cl})$.

The study respected the principles of Resolution No. 466/12, of the National Health Council.

\section{RESULTS}

The research was conducted with 303 adolescents, of whom $54.7 \%$ boys ( $n=158)$, with a mean age of 14 years old In maternal schooling, there was predominance of elementary schooling, with $34.7 \%$ of the mothers $(n=74)$ (Table 1$)$. 
Table 1 - Characterization of the sample of adolescents in the $9^{\text {th }}$ grade of elementary school, application of the general information module of PeNSE (2015), Divinópolis, MG, Brazil, 2017. ( $n=303$ )

\begin{tabular}{|c|c|c|}
\hline Variable & $\mathbf{n}$ & $\%$ \\
\hline \multicolumn{3}{|l|}{ Administrative dependency } \\
\hline State & 218 & 71.9 \\
\hline Private & 25 & 8.3 \\
\hline Municipal & 60 & 19.8 \\
\hline \multicolumn{3}{|l|}{ Gender* } \\
\hline Male & 158 & 52.3 \\
\hline Female & 144 & 47.7 \\
\hline \multicolumn{3}{|l|}{ Skin color† } \\
\hline White & 118 & 39.6 \\
\hline Black & 34 & 11.4 \\
\hline Asian & 11 & 3.7 \\
\hline Brown & 128 & 43.0 \\
\hline Indigenous & 7 & 2.3 \\
\hline \multicolumn{3}{|l|}{ Age $^{*}$} \\
\hline 13 years old & 9 & 3.0 \\
\hline 14 years old & 216 & 71.8 \\
\hline 15 years old & 58 & 19.3 \\
\hline 16 years old & 12 & 4.0 \\
\hline 17 years old & 5 & 1.7 \\
\hline 19 years old or more & 1 & 0.3 \\
\hline \multicolumn{3}{|l|}{ Full-time } \\
\hline Yes & 18 & 6.2 \\
\hline \multicolumn{3}{|l|}{ Maternal schooling§ } \\
\hline Up to elementary school & 74 & 34.7 \\
\hline High School & 68 & 31.9 \\
\hline Higher Educ. & 71 & 33.3 \\
\hline
\end{tabular}

*1 interviewee without information $(0.3 \%) ; \dagger 5$ interviewees without information (1.7\%); $\ddagger 11$ interviewees without information (3.6\%); $§ 7$ interviewees without information $(2.3 \%)$.

Table 2 shows the information related to the sociodemographic data and the univariate analysis of the factors associated with alcohol use by students.

In characterizing the environment and social relationships of these adolescents (Table 2), it was questioned as to the expected schooling, with a predominance of students who intended to attend graduate school with $54.7 \%(n=162)$, followed by completing undergraduate studies and not knowing what to do, both with the same percentage of $15.5 \%(n=46)$. As for what they expected to do when the school cycle ended, most expected to continue studying and working, with $60.8 \%$ of the respondents $(n=180)$. Only continuing to study appeared in $14.2 \%$ of the questionnaires $(n=42)$.

Regarding the adolescent working, it was identified that the largest portion did not do so, with the percentage not having any type of remuneration: $79.3 \%(n=238)$. Regarding the adolescent's environment and social network, 91.2\% $(n=249)$ of the adolescents' friends used alcohol. As for the question of who they lived with, $64 \%(n=190)$ lived with both of their parents. The description of the characteristics of the use of beverages is shown in Table 3. 
Table 2 - Sociodemographic description and univariate analysis assessing the factors associated to alcohol consumption, Divinópolis, MG, Brazil, 2017. $(n=298)$

\begin{tabular}{|c|c|c|c|c|}
\hline & Total Frequency & $\begin{array}{l}\text { Prevalence of } \\
\text { alcohol use }\end{array}$ & p-value & PR $[95 \% \mathrm{Cl}]$ \\
\hline \multicolumn{5}{|l|}{ Administrative dependency } \\
\hline Private & $25(8.3 \%)$ & $8(32.0 \%)$ & 0.055 & 1 \\
\hline Public & $278(91.7 \%)$ & $142(52.0 \%)$ & & $1.63[0.91 ; 2.91]$ \\
\hline \multicolumn{5}{|l|}{ Gender } \\
\hline Female & $144(47.7 \%)$ & $66(46.2 \%)$ & 0.166 & 1 \\
\hline Male & $158(52.3 \%)$ & $84(54.2 \%)$ & & $1.17[0.93 ; 1.48]$ \\
\hline \multicolumn{5}{|l|}{ Expected schooling } \\
\hline Postgraduate course & $162(54.7 \%)$ & $76(47.2 \%)$ & 0.052 & \\
\hline Upper & $46(15.5 \%)$ & $20(43.5 \%)$ & & $0.92[0.64 ; 1.33]$ \\
\hline Up to high-technical school & $42(14.2 \%)$ & $28(70.0 \%)$ & & $1.48[1.14 ; 1.92]$ \\
\hline Does not know & $46(15.5 \%)$ & $24(52.2 \%)$ & & $1.11[0.80 ; 1.52]$ \\
\hline \multicolumn{5}{|l|}{ Pretension after school cycle } \\
\hline Only continue studying & $42(14.2 \%)$ & $9(21.4 \%)$ & 0.001 & 1 \\
\hline Only work & $19(6.4 \%)$ & $12(66.7 \%)$ & & $3.11[1.60 ; 6.06]$ \\
\hline Study and work & $180(60.8 \%)$ & $98(54.7 \%)$ & & $2.55[1.41 ; 4.63]$ \\
\hline Pursue another plan & $17(5.7 \%)$ & $7(41.2 \%)$ & & $1.92[0.85 ; 4.33]$ \\
\hline I don't know & $38(12.8 \%)$ & $20(55.6 \%)$ & & $2.59[1.35 ; 4.96]$ \\
\hline \multicolumn{5}{|l|}{ Have some job } \\
\hline No & $238(79.3 \%)$ & $111(47.2 \%)$ & 0.036 & 1 \\
\hline Yes & $62(20.7 \%)$ & $38(62.3 \%)$ & & $1.32[1.04 ; 1.67]$ \\
\hline \multicolumn{5}{|l|}{ Remuneration } \\
\hline No & $237(79.3 \%)$ & $111(47.4 \%)$ & 0.066 & 1 \\
\hline Yes & $62(20.7 \%)$ & $37(60.7 \%)$ & & $1.27[1.01 ; 1.63]$ \\
\hline \multicolumn{5}{|l|}{ Maternal schooling } \\
\hline Up to elementary school & $74(34.7 \%)$ & $39(53.4 \%)$ & 0.485 & 1 \\
\hline High School & $68(31.9 \%)$ & $29(43.3 \%)$ & & $0.81[0.57 ; 1.15]$ \\
\hline Higher Educ. & $71(33.3 \%)$ & $34(47.9 \%)$ & & $0.90[0.65 ; 1.24]$ \\
\hline \multicolumn{5}{|l|}{ Who do you live with } \\
\hline Mother and father & $190(64.0 \%)$ & $86(45.7 \%)$ & 0.023 & 1 \\
\hline Only mother & $95(32.0 \%)$ & $51(54.8 \%)$ & & $1.20[0.94 ; 1.53]$ \\
\hline Neither father nor mother & $12(4.0 \%)$ & $10(83.3 \%)$ & & $1.82[1.35 ; 2.45]$ \\
\hline \multicolumn{5}{|l|}{ Friends who drink } \\
\hline No & $24(8.8 \%)$ & $3(13.0 \%)$ & $<0.001$ & 1 \\
\hline Yes & $249(91.2 \%)$ & $139(56.0 \%)$ & & $4.30[1.48 ; 12.44]$ \\
\hline
\end{tabular}


Table 3 - Characterization of the questionnaire data on alcohol consumption, $9^{\text {th }}$ grade elementary school students, Divinópolis, MG, Brazil, 2017. $(n=298)$

\begin{tabular}{|c|c|c|}
\hline & $\mathbf{n}$ & $\%$ \\
\hline \multicolumn{3}{|c|}{ Drank one dose of alcoholic beverage } \\
\hline No & 150 & 50.3 \\
\hline Yes & 148 & 49.7 \\
\hline \multicolumn{3}{|l|}{ Age when started drinking } \\
\hline Mean \pm standard deviation & $12.8 \pm 1.9$ & \\
\hline Median (minimum - maximum) & $13(7-16)$ & \\
\hline \multicolumn{3}{|c|}{ How many days did you drink in the last 30 days } \\
\hline None & 227 & 76.9 \\
\hline 1 or more days & 68 & 23.1 \\
\hline \multicolumn{3}{|c|}{ How many glasses have you drunk in the last 30 days } \\
\hline None & 223 & 75.6 \\
\hline Less than a glass & 47 & 15.9 \\
\hline 1 glass or 1 dose or more & 25 & 8.5 \\
\hline \multicolumn{3}{|c|}{ How many times did you get drunk in your life } \\
\hline None & 236 & 81.4 \\
\hline 1 or 2 times & 31 & 10.7 \\
\hline 3 or more times & 23 & 7.9 \\
\hline \multicolumn{3}{|c|}{ How many times in your life did you have problems because of alcohol } \\
\hline None & 273 & 91.9 \\
\hline 1 or more times & 24 & 8.0 \\
\hline \multicolumn{3}{|l|}{ Friends who drink } \\
\hline No & 24 & 8.8 \\
\hline Yes & 249 & 91.2 \\
\hline
\end{tabular}

In the description of the characteristics of beverage use (Table 3), information was obtained from 298 questionnaires, with a use prevalence of $50.3 \%$ in the sample $(n=150)$. The frequency of consumption of beverages in the last 30 days was analyzed, with predominance of non-use, with $75.6 \%(n=223)$ and mean age to start drinking at 13 years old $(12.8 \pm 1.9)$.

When the univariate analysis of the factors associated with alcohol consumption was performed (Table 2), these were significant $(p<0.05)$ in the following associations: What do adolescents intend to do when the school cycle is over, if they work, who they live with and friends who drink. The administrative dependency, expected schooling and if they have a salary factors had borderline significance ( $p$-value close to $5 \%$ ).

Higher lifetime alcohol consumption was observed in the univariate analysis among public school adolescents ( $\mathrm{PR}=1.63 ; 95 \% \mathrm{Cl}=0.91-2.91)$, whose expected schooling was up to high school/ technical ( $P R=1.48 ; 95 \% \mathrm{Cl}=1.14-1.92)$, who only intended to work when the school cycle ends $(\mathrm{PR}=3.11 ; 95 \% \mathrm{Cl}=1.60-6.06)$, who worked $(\mathrm{PR}=1.32 ; 95 \% \mathrm{Cl}=1.04-1.67)$ and were paid $(\mathrm{PR}=1.27$; 95\% $\mathrm{Cl}=1.01-1.63$ ), who did not live with any of their parents ( $\mathrm{PR}=1.82 ; 95 \% \mathrm{Cl}=1.35-2.45)$, and who had friends who drink ( $P R=4.30 ; 95 \% \mathrm{Cl}=1.48-12.44)$. The results of the multivariate analysis are shown in the table below (Table 4). 
Table 4 - Multivariate analysis evaluating the factors associated with alcohol consumption, $9^{\text {th }}$ grade elementary school students, Divinópolis, MG, Brazil, 2017. $(n=298)$

\begin{tabular}{lcc}
\hline \multicolumn{1}{c}{ Variable } & p-value & PR [95\%Cl] \\
\hline Expected schooling & & 1 \\
Postgraduate course & & $0.86[0.58 ; 1.28]$ \\
Higher Educ. & 0.452 & $1.47[1.11 ; 1.94]$ \\
Up to high-technical school & 0.007 & $1.19[0.87 ; 1.61]$ \\
Does not know & 0.271 & \\
Pretension after school cycle & & 1 \\
Only continue studying & & $1.94[0.95 ; 3.95]$ \\
Only work & 0.067 & $2.36[1.33 ; 4.19]$ \\
Study and work & 0.003 & $1.82[0.82 ; 4.05]$ \\
Pursue another plan & 0.141 & $2.30[1.21 ; 4.38]$ \\
I don't know & 0.011 & 1 \\
Have some job & & $1.87[1.54 ; 2.28]$ \\
No & & \\
Yes & $<0.001$ & 1 \\
Who do you live with & & $3.87[0.89 ; 1.47]$ \\
Mother and father & & $1.44[1.09 ; 1.90]$ \\
Only mother & 0.281 & \\
Neither father nor mother & 0.010 & 1 \\
Friends who drink & & $3.87[1.40 ; 10.66]$ \\
No & 0.009 & \\
Yes & &
\end{tabular}

The associations found in the multivariate analysis were the following: expected schooling, what they want to do when the school cycle ends, if they work, who they live with, and friends who drink ( $p$-values<0.05).

According to these results, the adolescents who only intend to study until high school or technical school are 1.47 times more likely to have already consumed alcohol than those who intend to study until graduate school $(95 \% \mathrm{Cl}=1.1 ; 1-1.94)$.

When analyzing what they intend to do after the end of the school cycle, those who only hope to work are 1.94 times more likely to have already consumed alcohol when compared to those who only intend to continue studying (borderline significance $-95 \% \mathrm{Cl}=0.95 ; 3.95$ ). For students who have not yet decided what to do next, the probability increases to 2.30 times ( $95 \% \mathrm{Cl}=1.21-4.38)$. However, the greatest probability that they have already used alcohol is in students who intended to work and study after the school cycle, with a 2.36 times $(95 \% \mathrm{Cl}=1.33-4.19)$ higher probability than those who would only like to continue studying.

Working adolescents are 1.87 times more likely to have consumed alcohol in their lifetime (95\% $\mathrm{Cl}=1.54-2.28)$. As for the association between living with parents and using alcoholic beverages, it is observed that adolescents who do not live with their parents are 1.44 times more likely to have consumed alcoholic drinks than those living with their parents $(95 \% \mathrm{Cl}=1.09-1.90)$. Finally, there is an association between the use of beverages and having friends who drink $(P R=3.87 ; 95 \% C l=1.40-10.66)$. 


\section{DISCUSSION}

The use of alcoholic beverages among adolescents is an observable factor in the present study, as well as its early onset. A reality present not only in the country, but also in international studies. In Mexico, $60.6 \%$ of the adolescents aged 13-14 years old had tried alcoholic drinks in 2015; this rate is even higher in Portugal, with $80.5 \%$ of the adolescents reporting the use of drinks at some point in their lives. ${ }^{16-17}$

The prevalence of alcohol use in the month found in the present study (23.1\%) agreed with $\operatorname{PeNSE}(2015)^{6}$ and with a study carried out in Diadema, São Paulo, in which there was a prevalence of use of $22.6 \%$ among the adolescents. ${ }^{18}$ However, the study conducted in Portugal shows an alarming rate of lifetime use of alcohol by adolescents, with $80.5 \%$ of the respondents reporting the use of drinks at some point in life..$^{19}$

Alcohol experimentation occurred in early adolescence, which is in agreement with the literature..$^{8,11}$ The early and regular use of alcohol by adolescents is responsible for physiological, psychological and immunological changes, since the body of the adolescents is maturing. ${ }^{20}$ In addition to physical impairments, alcohol influences behavior, leading to increased aggression and intolerance, as well as exposure to aggression and accidents. ${ }^{19}$

As for the use of alcohol among boys and girls, the present research brought greater use among males, which does not agree with PeNSE (2015), ${ }^{6}$ in which consumption was higher among girls. Research studies carried out in Mexico and Hungary, on the other hand, corroborate the present study. ${ }^{17,21}$ But, despite the prevalence of use in boys, there was no significant association between alcohol use and the gender variable.

A possible explanation for this non-association would be that the use of alcohol by adolescents has other associated factors that are more relevant than gender, since there have been cultural changes in the last decades that no longer differentiate the use between men and women. ${ }^{11,15,22-23}$

Among the factors that are associated with the use of alcohol by adolescents, social relations and the environment in which these individuals circulate stand out. These connections and paths influence their future choices and expectations. In a research study, it was found that most adolescents aim to attend graduate school, but that they work at the same time. This future planning is related to having a degree but, at the same time, an income that will ensure insertion in the adult world. ${ }^{24}$

Adolescents who aspire to this planning are more likely to use drinks than those who only wish to study after the end of the school cycle. A fact related to contemporaneity, in which the use of psychoactive substances is considered a consumer good. ${ }^{25}$

Thus, young people who already use drinks expect their maintenance in adulthood, as they circulate and relate to people with the same standards and habits, constituting their social network, which influences them to want a job that generates income for their maintenance. This income will provide young people to attend parties and places with the use of drinks, which are considered influential and socially desired environments. ${ }^{26}$

The media itself and sporting events raise these expectations among adolescents. Many soccer teams and cultural events are sponsored by beer brands, as well as films and soap operas relate the use of alcohol to social disinhibition and more pleasant environments. ${ }^{27}$

The use of drinks by these young people who wish to work and see themselves emancipated was also found in a study carried out in Australia, in which, in the last school year, they held parties where there was extensive use of drinks, perceived as a ritual of transition into adulthood, where parents and teachers would exert surveillance. ${ }^{27}$

As for the adolescent who already works, the present study found an association with the use of alcohol. There are no research studies in the literature that directly associate the use of alcohol 
and work by adolescents. The question of family income is more discussed in the surveys, but without consensus. A study conducted in Uberlândia/MG associated higher consumption in families with incomes of up to one minimum wage,${ }^{23}$ whereas other studies did not relate the use of beverages and per capita income..$^{3,28}$

In the case of the study in question, attention must be paid to the adolescentıs work and to the importance of the social relationships created. When inserted in a job market, adolescents start to live with other social groups, and the individualıs self-concept depends largely on the group to which they belong or are inserted at the moment. ${ }^{26}$ Thus, living in workplaces with adults or other young people who use drinks can lead them to social learning. ${ }^{16,26,29}$

Another important analysis that relates to the environment and to the relationships established by these young individuals is that of the family nucleus. This can inform the socioeconomic level and degree of social vulnerability of the young individual. In the survey, nuclear families predominated, with $64 \%(n=190)$, a percentage slightly higher than that of PeNSE (2015) with $59.4 \%$ of the adolescents living with both of their parents. ${ }^{6}$

When alcohol use and family context were related, the adolescents who do not live with their parents are more likely to use alcohol. This result appears in other research studies on the subject. Not having the parents present or having less parental surveillance increases the chances of alcohol use by the adolescents. ${ }^{22}$

The presence of both parents can be seen as a facilitator for surveillance and the imposition of limits. A research study carried out in England reports that the consumption of beverages by adolescents depends on the parents> communication with them, in addition to imposing limits. Being that one of the main concerns of parents would not be with the consumption itself, but with the amount of drink ingested. ${ }^{30}$

It is noteworthy that $32 \%(n=95)$ of the interviewees lived only with their mother, a percentage close to that of PeNSE (2015) $)^{6}$, which was $30 \%$. Being a national reality, which imposes an overload on female responsibilities in women, who need to lead the family and take care of the children. ${ }^{12}$ it is known that most women receive less money than men, in addition to often having a greater workload, which can make parental surveillance more difficult.

Maternal schooling can be used as a socioeconomic marker and an association was expected with the use of drinks, but there was no significant association. Maternal schooling in the survey was higher than that found in PeNSE (2015), ${ }^{6}$ being that maternal higher education was informed by $33.3 \%(n=77)$ of the adolescents, when in PeNSE (2015) the percentage was $13.3 \%{ }^{6}$

The literature shows that low maternal schooling is related to lower income and to an increase in social vulnerability. A research study also reports that low income and its vulnerability have worse consequences when it comes to families headed by women, as they and their adolescents have selfresponsibility about the reality experienced, often leading this family to alcohol abuse and school dropout. ${ }^{31}$

This association was not found in the research, as already reported. What can explain the fact is that, in a medium-sized city in the inland of Minas Gerais, such as the one in the research, the interpersonal, socialization and circulation factors of the individuals in the environments are more important than income, since adolescents with lower incomes circulate in the same party and drinking environments as those with higher incomes.

This can also be seen when there was no association in the multivariate analysis between the school administrative dependency and the use of beverages. Only in the univariate analysis does this variable appear with borderline association, showing that studying in a public school would be a risk factor for alcohol use. PeNSE (2015) ${ }^{6}$ shows a prevalence of alcohol use by adolescents in public schools of $56.2 \%$, whereas the present study showed a prevalence of $52 \%(n=142)$ in students from public school, but without association in the multivariate analysis. 
The adolescents network of friends deserves to be highlighted, being the strongest association present in the research. In the survey, it was found that $91.2 \%(n=249)$ of the adolescents have friends who drink; in PeNSE (2015) this number was lower, with $43.8 \%$ of the students claiming to have friends who consume alcoholic drinks (PeNSE, 2015). ${ }^{6}$

Regarding this theme, a study conducted in the United States of America shows that adolescents who drink are more outgoing and tend to befriend more easily. ${ }^{26}$ Belonging to a more outgoing circle of friends is an ambition for many young people, and adolescents who have stopped using psychoactive substances have greater difficulties in finding new friendships, being excluded from various social groups. ${ }^{31}$

A research study showed that having friends who drink increases almost four times the adolescentss chances of drinking, which corroborates the literature on the adolescentss need to belong to a group. Adolescents who use alcoholic beverages tend to select individuals with the same behavior for their social group, as well as those who do not drink can start using it to be accepted in these social groups. ${ }^{18}$

It is noteworthy that, for an analysis of the influence of friends on the use of beverages, the scope should be expanded, capturing the friends from churches, neighborhoods and clubs. As in a research study that demonstrated that more vulnerable groups have more friends from their community and the local church, reducing the use of beverages, while less vulnerable adolescents tend to a binge drinking consumption pattern. ${ }^{18}$

The research study herein presented has the limitation of not differentiating the type of friendship, only the general association of this category being known. Therefore, new studies on the friendship network and the use of drinks are extremely important to understand the relationship between friendship and the use of drinks by adolescents.

The theme presented is complex, since alcohol is culturally accepted and has an important socializing factor. ${ }^{28}$ It is impossible to analyze the phenomenon from a single point of view. The social relationships and environments of these adolescents deserve to be highlighted in this research, but the biological, family and psychological characteristics are part of the context and should be researched and deepened. ${ }^{21}$

The second obstacle is the educators > own training, which comes from a community with values and truths, and that during their graduation the knowledge passed on ensures the reproduction of a social context. However, in schools where the professionals and the coordination itself are able to question this social reproduction and create an environment where the theme is treated openly, there is a chance for a behavioral change. Thus, one of the important focuses for prevention and health promotion involves enhancing the school environment, with the creation of programs aimed at a constructive and critical dialog on the theme of alcohol and other drugs. ${ }^{32}$

The research was of the self-application type; therefore, some inconsistencies may occur. ${ }^{33}$ In a study carried out on the consistency of the PeNSE answers in 2009 and 2012, the authors indicated that the self-reports about risky behavior, especially among adolescents, can be omitted or underestimated by the respondents sear or shame. ${ }^{34}$ As a control factor, precautions were taken to minimize inconsistencies.

\section{CONCLUSION}

The use of alcohol is socially accepted in the country, and is even encouraged by the media and by the family members. Analyzing the factors that lead adolescents to use it is complex and multifactorial. The analysis must cover macro- and micro-social factors. The main association was the use of alcohol and its social relationships, and that the adolescent has a need for group acceptance and belonging, which influences the choices of friends and their future perspectives. 
Friends stand out as a strong factor for the use of alcohol among adolescents. Further research studies are needed to deepen the theme, highlighting the place where this friendship was established and the living environment of these adolescents, thus tracing the influence of friendships on the use or not of alcohol.

As for the comparison with the results of PeNSE (2015), there were similarities between the two samples, therefore demonstrating that the use of alcohol is not restricted to large cities in the country, with similar use rates in inland cities, showing that the use of alcohol is a phenomenon that goes beyond borders and is found rooted in Brazilian society.

It is believed that this research can increase knowledge about the factors related to alcohol use by adolescents, by bringing data that elucidate the reason for this phenomenon. Based on the results, the actions and interventions on the subject must not only focus on the individuals, but on their social group. As a limitation, there is the self-application of the questionnaires and the selection of only students from the $9^{\text {th }}$ grade of elementary school.

\section{REFERENCES}

1. Jones SC. Parental provision of alcohol: a TPB-framed review of the literature. Health Promot Int [Internet]. 2016 [cited 2019 June 25];31:562-71. Available from: https://doi.org/10.1093/heapro/ dav028

2. Ferreira LN, Bispo Júnior JP, Sales ZN, Casotti CA, Braga Junior ACR. Prevalência e fatores associados ao consumo abusivo e a dependência de álcool. Ciênc Saúde Coletiva [Internet]. 2013 [cited 2018 Oct 20];18(11):3409-18. Available from: https://doi.org/10.1590/S141381232013001100030

3. Torronen J, Roumeliotis F, Samuelsson E, Kraus L, Room R. Why are people drinking less than earlier? Identifying and specifying social mechanisms with a pragmatist approach. Int J Drug Policy [Internet] 2019 [cited June 25 2019];64:13-20. Available from: https://doi.org/10.1016/j. drugpo.2018.12.001

4. Laranjeira R, organizador. II Levantamento Nacional de Álcool e Drogas (LENAD) - 2012. São Paulo, SP(BR): Instituto Nacional de Ciência e Tecnologia para Políticas Públicas de Álcool e Outras Drogas (INPAD), UNIFESP; 2014.

5. Damacena GN, Malta DC, Boccolini CS, Souza Júnior PRB, Almeida WS, Ribeiro LS, et al. Alcohol abuse and involvement in traffic accidents in the Brazilian population, 2013. Ciênc Saúde Colet [Internet]. 2016 [cited 2019 June 25];21(12):3777-86. Available from: https://doi. org/10.1590/1413-812320152112.25692015

6. Instituto Brasileiro de Geografia e Estatística. Pesquisa Nacional de Saúde Escolar 2015. Rio de Janeiro, RJ(BR): Instituto Brasileiro de Geografia e Estatística; 2016.

7. Raposo JCS, Costa ACQ, Valença PAM, Zarzar PM, Diniz AS, Colares V, et al. Binge drinking and illicit drug use among adolescent students. Rev Saúde Pública [Internet]. 2017 [cited 2018 Oct 20];51:83. Available from: https://doi.org/10.11606/s1518-8787.2017051006863

8. Neves KC, Teixeira MLO, Ferreira MA. Fatores e motivação para o consumo de bebidas alcoólicas na adolescência. Esc Anna Nery [Internet]. 2015 [cited 2018 Oct 20];19(2):286-91. Available from: http://www.scielo.mec.pt/scielo.php?script=sci_arttext\&pid=S1645-00862015000300010\&lng=pt

9. Gomes K, Amato TC, Bedendo A, Santos EL, Noto AR. Problemas associados ao binge drinking entre estudantes das capitais brasileiras. Ciênc Saúde Coletiva [Internet]. 2019 [cited June 25 2019];24(2):497-507. Available from: https://doi.org/10.1590/1413-81232018242.35452016 
10. Bowden JA, Delfabbro P, Room R, Miller CL, Wilson C. Prevalence, perceptions and predictors of alcohol consumption and abstinence among South Australian school students: a cross-sectional analysis. BMC Public Health [Internet]. 2017 [cited 2019 June 25];17(1):549. Available from: https://doi.org/10.1186/s12889-017-4475-5

11. Reis TG, Oliveira LCM. Pattern of alcohol consumption and associated factors among adolescents students of public schools in an inner city in Brazil. Rev Bras Epidemiol [Internet]. 2015 [cited 2018 Oct 20];19(1):13-24. Available from: https://doi.org/10.1590/1980-5497201500010002

12. Locatelli D, Sanchez Z, Opaleye E, Carlini C, Noto A. Socioeconomic influences on alcohol use patterns among private school students in São Paulo. Rev Bras Psiquiatr [Internet]. 2012 [cited 2018 Oct 20];34(2):193-200. Available from: https://doi.org/10.1590/S1516-44462012000200012

13. Malta DC, Mascarenhas MDM, Porto DL, Barreto SM, Morais Neto OLM. Exposure to alcohol among adolescent students and associated factors. Rev Saúde Pública [Internet]. 2014 [cited 2019 Jun 25];48(1):52-62. Available from: https://doi.org/10.1590/S0034-8910.2014048004563

14. Paiva PCP, Paiva HN, Lamounier JÁ, Ferreira EF, César CAS, Zarzar PM. Consumo de álcool em binge por adolescentes escolares de 12 anos de idade e sua associação com sexo, condição socioeconômica e consumo de álcool por melhores amigos e familiares. Ciênc Saúde Colet [Internet]. 2015 [cited 2018 Oct 20];20(11):3427-35. Available from: https://doi.org/10.1590/1413812320152011.18792014

15. Faria-Filho EA. Perfil do consumo de álcool e drogas ilícitas entre adolescentes escolares de uma capital Brasileira. SMAD, Rev Eletr Saúde Mental Álcool Drog [Internet]. 2014 [cited 2018 Oct 20];10(2):78-84. Available from: https://doi.org/10.11606/issn.1806-6976.v10i2p78-84

16. Deodato S, Nunes E, Capelas M, Seabra P, Sarreira-Santos A, Medeiros-Garcia L. Risk behaviors to psychoactive substances use in children and young people in Lisbon. Enferm Glob [Internet]. 2017 [cited 2018 Oct 20];16(47):98-127. Available from: https://doi.org/10.6018/eglobal.16.3.253011

17. Puente LAR, Castillo BAA, Castillo MMA, Castillo MTA, Garcia NAA, Rodriguez NNO. Consumo de alchohl y tabaco em adolescentes. SMAD, Rev Eletr Saúde Mental Álcool Drog [Internet]. 2016 [cited 2018 Oct 20];12(4):200-26. Available from: https://doi.org/10.11606/issn.1806-6976. v12i4p200

18. Malbergier A, Cardoso LRD, do Amaral RA. Uso de substâncias na adolescência e problemas familiares. Cad Saúde Pública [Internet]. 2012 [cited 2018 Oct 20];28(4):678-88. Available from: https://doi.org/10.1590/S0102-311X2012000400007

19. Jorge O, Ferreira RC, Ferreira EP, Vale MP, Kawachi I, Zorzar PM. Binge drinking and associated factors among adolescents in a city in southeastern Brazil: a longitudinal study. Cad Saúde Pública [Internet]. 2017 [cited 2019 June 25];33(2):e00183115.Available from: https://doi.org/10.1590/0102$311 \times 00183115$

20. Coutinho BLM, Feitosa AA, Diniz CBC, Ramos JLS, Ribeiro LZ, Amorim SR, et al. Alcohol and drugs in adolescence: work process in health in school program. J Human Growth Develop [Internet]. 2017 [cited 2018 Oct 20];27(1):28-34. Available from: https://doi.org/10.7322/jhgd.127646

21. Varga S, Piko BF. Being lonely or using substances with friends? A cross- setional study of Hungarian adolescents' health risk behaviours. BMC Public Health. [Internet]. 2015 [cited 2018 Oct 20];12:1107. Available from: https://doi.org/10.1186/s12889-015-2474-y

22. Malta DC, Oliveira- Campos M, Prado RR, Andrade SSCA, Mello FCM, Dias AJR et al. Psychoactive substance use, family context and mental health among Brazilian adolescents, National Adolescent School-based Health Survey (PeNSE 2012). Rev Bras Epidemiol [Internet]. 2014 [cited 2018 Oct 20];Suppl:46-61. Available from: https://doi.org/10.1590/1809-4503201400050005 
23. Silveira RE, Santos AS, Pereira GA. Consumo de álcool, tabaco e outras drogas entre adolescentes do ensino fundamental de um município brasileiro. Rev Enf Ref [Internet]. 2014 [cited 2018 Oct 20];IV(2):51-60. Available from: https://doi.org/10.12707/RIII12112

24. Almeida RMM, Trentini LB, Klein LA, Macuglia GR, Hammer C, Hammer M. Uso de álcool, drogas, níveis de impulsividade e agressividade em adolescentes do Rio Grande do Sul. Psico (Porto Alegre) [Internet]. 2014 [cited 2018 Oct 20];45(1):65-72. Available from: https://doi. org/10.15448/1980-8623.2014.1.12727

25. Almeida ND. Uso de álcool, tabaco e drogas por jovens e adultos da cidade de Recife. Psicol Argum [Internet]. 2011 [cited 2018 Oct 20];29(66):295-302. Available from: https://periodicos. pucpr.br/index.php/psicologiaargumento/article/view/20285

26. Huang GC, Soto D, Fujmoto K, Valente T. The interplay of friendship networks and social networkin sites: longitudinal analysis of selecion and influence effects on adolescente smoking and alcohol use. Am J Public Health [Internet]. 2014 [cited 2018 Oct 20];104(8):51-59. Available from: https:// doi.org/10.2105/AJPH.2014.302038

27. Pettigrew S, Biagioni N, Jongenelis MI. Anticipating and addessing event-specific alcohol consumption among adolescentes. BMC Public Health [Internet]. 2016 [cited 2018 Oct 20];16:661. Available from: https://doi.org/10.1186/s12889-016-3355-8

28. Jorge KO, Ferreira RC, Ferreira EF, Vale MP, Kawaci I, Zarzar PM. Bingr drinking and associated factors among adolescentes in a city in southeastern Brazil. a longitudinal study. Cad Saúde Pública [Internet] 2017 [cited 2018 Oct 20];33(2):e00183115. Available from: https://doi.org/10.1590/0102$311 \times 00183115$

29. Whiteman SD, Jensen AC, Maggs J. Similarities and diferences in adolescentes sibling's alchohol - related atitudes, use, adn delinquency: evidence for convergente and divergente influence processes. J Youth Adolesc [Intermet]. 2014 [cited 2018 Oct 20];43(5):687-97. Available from: https://doi.org/10.1007/s10964-013-9971-z

30. Jacob N, MacArthur GJ, Hickman M, Campbell R. A qualitative investigation of the role of the Family in structuring Young people's alcohol use. Europ J Public Health [Internet]. 2015 [cited 2018 Oct 20];26(1):102-10. Available from: https://doi.org/10.1093/eurpub/ckv123

31. Galhardi CC, Matsukura TS. O cotidiano de adolescentes em um Centro de Atenção Psicossocial de Álcool e outras Drogas: realidades e desafios. Cad Saúde Pública [Internet]. 2018 [cited 2018 Oct 20];34(3):e00150816. Available from: https://doi.org/10.1590/0102-311x00150816

32. Buss PM, Pellegrini Filho A. A saúde e seus determinantes sociais. Physis (Rio J). [Internet]. 2007 [cited June 26 2019];17(1):77-93. Available from: https://doi.org/10.1590/S010373312007000100006

33. Santos ARP, Jaqueline GA, Silva TTM, Lopes MVO, Frazão IS. Instruments related to drug use in adolescents: an integrated review. Texto Contexto Enferm [Internet]. 2018 [cited 2019 Feb 04];27(3):e0370017. Available from: https://doi.org/10.1590/0104-07072018000370017

34. Ramos DO, Daly M, Seidl-de-Moura ML, Jomar RT, Nadanovsky P. Inconsistent reports of risk behavior among Brazilian middle school students: National School Based Survey of Adolescent Health (PeNSE 2009/2012). Cad Saúde Pública [Internet]. 2017 [cited 2018 Oct 20];33(4):e00145815. Available from: https://doi.org/10.1590/0102-311×00145815 


\section{NOTES}

\section{CONTRIBUTION OF AUTHORITY}

Study desing: Almeida CS, Lana FCF.

Data collection: Almeida CS.

Data analysis and interpretation: Almeida CS, Andrade SN, Abreu MNS.

Discussion of the results: Almeida CS, Lana FCF.

Writing and/or critical review of content: Almeida CS, Andrade SN, Abreu MNS, Lana FCF.

Review and final approval of the final version: Almeida CS, Andrade SN, Abreu MNS, Lana FCF.

\section{FUNDING INFORMATION}

Support of the Coordenação de Aperfeiçoamento de Pessoal de Nível Superior, CAPES - Brazil - Funding Code 001.

\section{APPROVAL OF ETHICS COMMITTEE IN RESEARCH}

Approved in the Research Ethics Committee of the Universidade Federal de Minas Gerais, under opinion No.2,007,097/2017, and Certificate of Presentation for Ethical Appraisal No. 65627317.2.0000.5149.

\section{CONFLICT OF INTEREST}

There is no conflict of interest.

\section{HISTORICAL}

Received: February 06, 2019.

Approved: October 04, 2019.

\section{CORRESPONDING AUTHOR}

Camila Souza de Almeida

csalmeida_1@hotmail.com 